\title{
Impaired NMDA Receptor-Mediated Postsynaptic Function and Blunted NMDA Receptor-Dependent Persistent Pain in Mice Lacking Postsynaptic Density-93 Protein
}

\author{
Yuan-Xiang Tao, ${ }^{1 \star}$ Gavin Rumbaugh, ${ }^{2 \star}$ Guo-Du Wang, ${ }^{3 \star}$ Ronald S. Petralia, ${ }^{4}$ Chengshui Zhao, ${ }^{1}$ Frederick W. Kauer, ${ }^{5}$ \\ Feng Tao, ${ }^{1}$ Min Zhuo, ${ }^{3}$ Robert J. Wenthold, ${ }^{4}$ Srinivasa N. Raja, ${ }^{1}$ Richard L. Huganir, ${ }^{2}$ David S. Bredt,${ }^{5}$ and \\ Roger A. Johns ${ }^{1}$ \\ ${ }^{1}$ Department of Anesthesiology and Critical Care Medicine and ${ }^{2}$ Howard Hughes Medical Institute, Department of Neuroscience, Johns Hopkins University \\ School of Medicine, Baltimore, Maryland 21287, ${ }^{3}$ Washington University Pain Center, Departments of Anesthesiology, Anatomy and Neurobiology, and \\ Psychiatry, Washington University School of Medicine, St. Louis, Missouri 63110, ${ }^{4}$ Laboratory of Neurochemistry, National Institute on Deafness and Other \\ Communication Disorders, National Institutes of Health, Bethesda, Maryland 20892, and ${ }^{5}$ Department of Physiology, University of California San \\ Francisco, San Francisco, California 94143-0444
}

Modification of synaptic NMDA receptor (NMDAR) expression influences NMDAR-mediated synaptic function and associated persistent pain. NMDARs directly bind to a family of membrane-associated guanylate kinases (MAGUKs) that regulate surface and synaptic NMDAR trafficking in the CNS. We report here that postsynaptic density-93 protein (PSD-93), a postsynaptic neuronal MAGUK, is expressed abundantly in spinal dorsal horn and forebrain, where it colocalizes and interacts with NMDAR subunits NR2A and NR2B. Targeted disruption of the PSD-93 gene reduces not only surface NR2A and NR2B expression but also NMDAR-mediated excitatory postsynaptic currents and potentials, without affecting surface AMPA receptor expression or its synaptic function, in the regions mentioned above. Furthermore, mice lacking PSD-93 exhibit blunted NMDAR-dependent persistent pain induced by peripheral nerve injury or injection of Complete Freund's Adjuvant, although they display intact nociceptive responsiveness to acute pain. PSD-93 appears to be important for NMDAR synaptic targeting and function and to be a potential biochemical target for the treatment of persistent pain.

Key words: PSD-93; NMDA receptors; surface expression; persistent pain; spinal cord, forebrain

\section{Introduction}

Neurotransmission requires spatial and functional assembly of signal transduction machinery at the plasma membrane. The postsynaptic density (PSD), an electron-dense cytoskeletal structure beneath the plasma membrane of excitatory synapses, is one site in which receptors, channels, and effectors organize to mediate signaling. Recent studies indicate that a family of membraneassociated guanylate kinases (MAGUKs) in the PSD may play a major role in synaptic localization of channels, signaling enzymes, and adhesion molecules (Craven and Bredt, 1998; Garner et al., 2000). Neuronal MAGUK proteins include PSD-93/ chapsyn-110 (Brenman et al., 1996; Kim et al., 1996), PSD-95/ synapse-associated protein (SAP)-90 (Cho et al., 1992; Kistner et al., 1993), SAP-97/hdlg (Muller et al., 1995), and SAP102 (Lau et

\footnotetext{
Received March 4, 2003; revised June 4, 2003; accepted June 10, 2003.

This work was supported by the Blaustein Pain Research Fund (Y.-X.T.), National Institutes of Health Grants R01 GM 49111 and NS 44219 (R.A.J.) and NS360017 (D.S.B.), Howard Hughes Medical Institute (R.L.H.), National Institute on Drug Abuse Grant NIDA10833 (M.Z.), National Institute of Neurological Disorders and Stroke Grant NINDS38680 (M.Z.), and the Christopher Reeves Paralysis Foundation (D.S.B.). We thank Dr. R.J.0'Brien, C. F. Levine, Dr. Y.-X. Wang, and Dr. P. Mao for technical assistance and Dr. R. A. Meyer for helpful discussion.

*Y.-X.T., G.R., and G.-D.W. contributed equally to this work.

Correspondence should be addressed to Yuan-Xiang Tao, Department of Anesthesiology and Critical Care Medicine, Johns Hopkins University School of Medicine, 355 Ross, 720 Rutland Avenue, Baltimore, MD 21205. E-mail: ytau@jhmi.edu.

Copyright $\odot 2003$ Society for Neuroscience $\quad$ 0270-6474/03/236703-10\$15.00/0
}

al., 1996), all of which consist of three tandem PDZ domains at the N-terminal side, an Src homology region 3 domain in the middle, and a guanylate kinase-like domain at the C-terminal end. PDZ domains of MAGUKs are motifs of $\sim 90$ amino acid repeats that have been recognized to mediate protein-protein interactions and to bind to short amino acid motifs at the $\mathrm{C}$ termini of interacting proteins at synapses (Sheng, 1996; Kornau et al., 1997).

The NMDA receptors (NMDARs) are MAGUK-interacting proteins (Kornau et al., 1995; Brenman et al., 1996; Kim et al., 1996; Lau et al., 1996) that regulate multiple functions in physiological and pathological processes, including the transmission and/or processing of pain signaling in the CNS (Dougherty and Willis, 1991; Basbaum and Woolf, 1999; Hewitt, 2000). Functional NMDARs are heteromeric complexes mainly consisting of NR1 and NR2 (NR2A-D) subunits. The NR2 can determine synaptic localization and function of the receptor, because deletion of the C-terminal tail of NR2 results in impaired NMDARmediated synaptic activity (Mori and Mishina, 1995; Sprengel et al., 1998; Cull-Candy et al., 2001). C-terminal tails of the NR2 subunits directly bind to MAGUK proteins via PDZ domain interaction at synapses (Kornau et al., 1995; Brenman et al., 1996; Kim et al., 1996; Lau et al., 1996). PSD-95 enhances NMDAR clustering at synapses and inhibits NR2B-mediated internaliza- 
tion (Roche et al., 2001). Coexpression of PSD-95 with NMDARs increases surface expression of NMDARs and enhances synaptic NMDAR function (Carroll and Zukin, 2002). It appears that MAGUKs as molecular scaffold proteins cluster and bind to NMDARs at synaptic membranes and modulate their synaptic function. Interestingly, PSD-95 mutant mice exhibit intact synaptic localization and postsynaptic function of NMDARs, although they reveal enhanced long-term potentiation and impaired spatial learning (Migaud et al., 1998). Thus the physiological and pathological functional significance of the NMDAR being targeted and clustered at synapses by MAGUK proteins in vivo is unclear.

In this paper we demonstrated that PSD-93 was critical for surface NMDAR expression, NMDAR-mediated postsynaptic function, and NMDAR-dependent persistent pain. It appears that the deficiency of PSD-93 results in impaired NMDAR-mediated postsynaptic functions and in blunted NMDAR-dependent persistent pain by the mechanism of surface NMDAR alteration.

\section{Materials and Methods}

Reverse transcriptase-PCR. The cDNA sequences encoding a portion of the PSD-93 gene were amplified by using the following synthetic oligonucleotide primers: PSD1 (5'-AGTACTGTGCTGAGAATGAC-3') and PSD2 (5'-GAAGCAGGCTCTATTGTTCG-3') for amplification of PSD-93 codon positions 514-1085. RNA samples $(1 \mu \mathrm{g})$ were reverse transcribed to generate first-strand cDNA. The PCR reactions were performed for 35 cycles. Each cycle included $35 \mathrm{sec}$ at $94^{\circ} \mathrm{C}, 45 \mathrm{sec}$ at $55^{\circ} \mathrm{C}$, and $1 \mathrm{~min}$ at $72^{\circ} \mathrm{C}$. The PCR products were cloned directly into the TA cloning vector (Invitrogen, San Diego, CA) and verified by automatic DNA sequencing.

Immunocytochemistry. Mice were perfused with $4 \%$ paraformaldehyde in $0.1 \mathrm{~m}$ PBS. The spinal cord was harvested and postfixed at $4^{\circ} \mathrm{C}$ for $4 \mathrm{hr}$ and cryoprotected in $30 \%$ sucrose overnight. Sections $(30 \mu \mathrm{m})$ were cut on a cryostat and then blocked for $1 \mathrm{hr}$ in PBS containing 10\% goat serum and $0.3 \%$ Triton X-100. Primary rabbit polyclonal anti-PSD-93 (1:1000) (Brenman et al., 1996, 1998; Roche et al., 1999; Sans et al., 2000; McGee et al., 2001) or NR2A/2B (1:100; Chemicon, Temecula, CA) (Petralia et al., 1994; Follesa and Ticku, 1996a,b) was diluted into blocking reagent and incubated with the sections overnight. The sections then were incubated in biotinylated goat anti-rabbit IgG (1:200; Vector Labs, Burlingame, $\mathrm{CA}$ ) for $1 \mathrm{hr}$ at $37^{\circ} \mathrm{C}$, followed by avidin-biotin-peroxidase complex (1:100; Vector Labs) for $1 \mathrm{hr}$ at $37^{\circ} \mathrm{C}$. The immune reaction product was visualized by catalysis of 3,3-diaminobenzidine by horseradish peroxidase in the presence of $0.01 \% \mathrm{H}_{2} \mathrm{O}_{2}$. Control sections lacking primary antiserum were stained in parallel.

Western blot analysis. The soluble protein or PSD fraction was prepared as described (Tao et al., 2000; Tao and Johns, 2002). The proteins were loaded onto $4 \%$ stacking/7.5\% separating SDS-polyacrylamide gels and then were transferred electrophoretically onto nitrocellulose membrane. The membrane was blocked with $2 \%$ nonfat dry milk and subsequently was incubated for $1 \mathrm{hr}$ with polyclonal rabbit anti-PSD-93 antibody (1:500) or with polyclonal rabbit antiNR2A antibody (1:500; Chemicon) or with polyclonal rabbit antiNR2B antibody (1:500) (Follesa and Ticku, 1996a,b; Shi et al., 1997). The proteins were detected by using horseradish peroxidaseconjugated anti-rabbit secondary antibodies and visualized by chemiluminescence reagents provided with the ECL kit (Amersham Biosciences, Piscataway, NJ) and exposure to film. The intensity of blots was quantified with densitometry.

Coimmunoprecipitation. The affinity-purified rabbit PSD-93 antiserum with or without preincubation with excess PSD-93 fusion protein $(100 \mu \mathrm{g} / \mathrm{ml})$ was incubated with $100 \mu \mathrm{l}$ of a $1: 1$ slurry of protein A-Sepharose for $1 \mathrm{hr}$, and the protein-antibody complex was spun down at $2000 \mathrm{rpm}$ for $4 \mathrm{~min}$. The solubilized PSD fraction $(400 \mu \mathrm{g})$ then was added to the Sepharose beads, and the mixture was incubated for $2-3 \mathrm{hr}$ at $4^{\circ} \mathrm{C}$. The mixture was washed once with $1 \%$ Triton $\mathrm{X}-100$ in immunoprecipitation buffer [containing (in $\mathrm{mM}$ ): $137 \mathrm{NaCl}, 2.7 \mathrm{KCl}, 4.3$ $\mathrm{Na}_{2} \mathrm{HPO}_{4}, 1.4 \mathrm{KH}_{2} \mathrm{PO}_{4}, 5$ EGTA, 1 sodium vanadate, 10 sodium pyrophosphate, $50 \mathrm{NaF}$, and 0.1 phenylmethylsulfonyl fluoride plus $20 \mathrm{U} / \mathrm{ml}$ Trasylol], twice with $1 \%$ Triton X-100 in immunoprecipitation buffer plus $300 \mathrm{~mm} \mathrm{NaCl}$, and three times with immunoprecipitation buffer. The proteins were separated by SDS-PAGE and detected by PSD-93, NR2A, or NR2B antibody as described above. As a positive control (Input), $40 \mu \mathrm{g}$ of the solubilized PSD fraction was loaded.

Electron microscopy. The postembedding immunogold labeling was done as described (Petralia and Wenthold, 1999; Sans et al., 2000). Briefly, male mice were perfused with $4 \%$ paraformaldehyde plus $0.5 \%$ glutaraldehyde. Sections $300 \mu \mathrm{m}$ each were prepared with a vibratome, frozen in liquid propane, and embedded in Lowicryl. Ultrathin sections were cut from blocks and processed for immunogold staining. For double labeling the first primary antibody and corresponding immunogoldconjugated (10 nm of gold) antibody were applied. Then the ultrasections were exposed to paraformaldehyde vapor at $80^{\circ} \mathrm{C}$ for $1 \mathrm{hr}$, and the second primary and secondary $(5 \mathrm{~nm})$ antibodies were applied the next day. Most of the primary antibodies were characterized previously (Petralia and Wenthold, 1999; Sans et al., 2000). Because individual NR2A or NR2B antibody that we used in the Western blotting described above is not recommended for immunogold staining (Sans et al., 2000), the primary antibodies used were PSD-93 $(1.7 \mu \mathrm{g} / \mathrm{ml}), \mathrm{NR} 1(4 \mu \mathrm{g} / \mathrm{ml})$, and $\mathrm{NR} 2 \mathrm{~A} / 2 \mathrm{~B}(4 \mu \mathrm{g} / \mathrm{ml})$. Thus electron microscopy showed a synaptic relationship of PSD-93 with NR1 or NR2A/2B (but not individual NR2A or $\mathrm{NR} 2 \mathrm{~B}$ ), whereas coimmunoprecipitation and surface expression assays revealed the interaction of PSD-93 with individual NR2A or NR2B. Controls included an absence of primary antibody for single labeling and an absence of the second primary antibody for double labeling. Controls always showed little or no gold labeling.

Behavioral testing. All behavioral experiments were performed with the approval of the Animal Care Committee at the Johns Hopkins University and were consistent with the ethical guidelines of National Institutes of Health and the International Association for the Study of Pain. To test baseline pain responses, we assessed mechanical withdrawal frequencies by application of different forces of calibrated von Frey monofilaments (mN: 0.24, 1.47, 4.33, 8.01, 23.69, 40.31) (Stoelting, Wood Dale, IL) to the plantar hind paw surface, and measured thermal withdrawal latencies after the application of radiant heat to the plantar hind paw surface (Mansikka et al., 2000; Tao et al., 2000). In Complete Freund's Adjuvant (CFA)-induced inflammatory pain, the mice received a $20 \mu \mathrm{l}$ intraplantar injection of CFA solution $(1 \mathrm{mg} / \mathrm{ml})$. Mechanical withdrawal frequencies were assessed by applying calibrated von Frey monofilaments 0.24 and $4.33 \mathrm{mN}$ to the plantar hind paw surface as described (Fairbanks et al., 2000; Mansikka et al., 2000). To quantify the inflammatory response, we measured the paw thickness with a caliper after CFA injection. To test neuropathic pain, we isolated the fifth lumbar nerve root, ligated it with a $6-0$ silk suture, and transected it just distal to the ligature in halothane-anesthetized mice. Control groups included naive or sham-operated (without nerve ligation) mice ( $n=5$ for each group). Mechanical withdrawal frequencies were assessed by applying calibrated von Frey filaments 0.24 and $4.33 \mathrm{mN}$ to the plantar hind paw surface. To observe the effect of MK-801 on CFA- or nerve injuryinduced mechanical hyperalgesia, we gave MK-801 (1.0 nmol/5 $\mu$ l; Research Biochemicals, Natick, MA) (Zushida and Kamei, 2002) intrathecally on day 3 after CFA injection or on day 6 after nerve injury as previously described. Mechanical withdrawal frequencies on both ipsilateral and contralateral sides were measured before drug injection and at $30 \mathrm{~min}$ after drug injection. In all of the behavioral studies described above, the observers were blind to the genotype of the mice.

Electrophysiological recordings. For patch-clamp recording of cultured neurons, spinal dorsal horn neuronal cultures were prepared as previously described (O'Brien et al., 1997). In brief, the neurons from embryonic day 14 mouse dorsal spinal cord were plated at 200,000 cells $/ \mathrm{ml}$. Recordings were performed at $9 \mathrm{~d}$ in vitro (9 DIV) from at least two platings for each genotype. Neurons were bathed in artificial CSF (ACSF) consisting of (in mM): $145 \mathrm{NaCl}, 10 \mathrm{HEPES}, 3 \mathrm{KCl}, 2 \mathrm{CaCl}_{2}, 10$ glucose, 
0.1 glycine, 0.001 TTX, 0.1 picrotoxin, and 0.002 strychnine. $\mathrm{MgCl}_{2}$, an open channel blocker of NMDARs, was omitted purposely from the recording solutions. The $\mathrm{pH}$ was adjusted to 7.4 , and the osmolarity was adjusted to 305-310. Intracellular saline consisted of (in mM): 135 cesium methane-sulfonate, $10 \mathrm{CsCl}$, 5 EGTA, 4 ATP-Na, 0.4 GTP-Na, 10 HEPES, and $1 \mathrm{MgCl}_{2}$. The $\mathrm{pH}$ was adjusted to 7.2 , and the osmolarity was adjusted to 290-295. Patch electrodes were fire polished and typically had resistance $<5 \mathrm{M} \Omega$. After the whole-cell configuration was achieved, the cell was allowed to stabilize for $\sim 2 \mathrm{~min}$ at a holding potential of -60 $\mathrm{mV}$. Data then were acquired continuously for $10-15 \mathrm{~min}$ at a sampling frequency of $10 \mathrm{kHz}$ with low-pass filtering at $1 \mathrm{kHz}$. Miniature EPSCs (mEPSCs) were selected and subsequently aligned with Mini Analysis software (Synatosoft, Decatur, GA). The average of at least 100 events for each cell was exported and then fit with a double-exponential function in the form:

$$
I(t)=I_{\text {fast }} \cdot \exp \left(-t / \tau_{\text {fast }}\right)+I_{\text {slow }} \cdot \exp \left(-t / \tau_{\text {slow }}\right),
$$

where $I_{\text {fast }}$ and $I_{\text {slow }}$ are the amplitudes of the fast and slow decay components, and $\tau_{\text {fast }}$ and $\tau_{\text {slow }}$ are their respective decay time constants used to fit the data. Curve fitting was performed with Clampfit 8.1 (Axon Instruments, Union City, CA).

For slice recordings the adult mice (8-12 weeks) were anesthetized with $1-2 \%$ halothane, and brain or spinal cord was isolated. Recordings from cortex were done as described (Wei et al., 2001). Briefly, transverse cortical slices were maintained in an interface chamber at $28^{\circ} \mathrm{C}$, where they were subfused with ACSF and bubbled with $95 \% \mathrm{O}_{2} / 5 \% \mathrm{CO}_{2}$. Slices were kept in the recording chamber for at least $2 \mathrm{hr}$ before experiments. A bipolar tungsten stimulating electrode was placed in layer $\mathrm{V}$, and extracellular field potentials were recorded with a glass microelectrode (3-12 M $\Omega$, filled with ACSF) placed in layer II/III. Experiments were performed blind, and the placement of stimulating and recording elec- trodes was kept consistent in different groups of mice. To block synaptic responses mediated by AMPA/kainate receptors, we applied $20 \mu \mathrm{M}$ CNQX throughout the experiments. As reported previously (Wei et al., 2001), the residual EPSPs were blocked completely and reversibly by the bath application of $100 \mu \mathrm{M}$ aminophosphonopentanoic acid (AP-5). Stimulation at different intensities was applied, and test responses were elicited at $0.02 \mathrm{~Hz}$. The measurement of field NMDAR-mediated EPSPs was performed blind to the wild-type or knock-out genotype. For recording from spinal cord, transverse spinal slices $(450-500 \mu \mathrm{m})$ with attached dorsal roots $(7-12 \mathrm{~mm}$ ) were prepared. Intracellular recordings of synaptic responses were performed from neurons located in the dorsal horn lamina I and II with a $3 \mathrm{~m}$ potassium chloride-filled glass microelectrode (DC impedance, 75-200 M $\Omega$ ). The synaptic responses were activated by electrical stimulation in dorsal roots with a bipolar electrode. EPSPs of the neurons were evoked with stimulation at various intensities $(10-40 \mathrm{~V}, 0.2 \mathrm{msec})$, recorded through a high-input impedance bridge circuit amplifier (Axoclamp 2B), and stored with pClamp software (Axon Instruments). The ACSF was oxygenated with $95 \% \mathrm{O}_{2} / 5 \% \mathrm{CO}_{2}$. The temperature and perfusion rate of recording were kept at $34^{\circ} \mathrm{C}$ and $2-5 \mathrm{ml} / \mathrm{min}$, respectively. The AMPA/kainate receptor antagonist CNQX $(20 \mu \mathrm{M})$ was included in the bath solution throughout the experiments. To reduce the magnesium blockade of NMDARs, we used $0.1 \mathrm{~mm}$ magnesium during the recordings of NMDAR-mediated responses. In all experiments bicuculline methiodide $(10 \mu \mathrm{M})$ and strychnine hydrochloride $(1 \mu \mathrm{M})$ were added to the perfusion solution to block inhibitory synaptic transmission.

Surface expression assays. Biotinylation experiments were performed as previously described (Roche et al., 2001; Snyder et al., 2001). Briefly, high-density cultured spinal dorsal horn neurons were prepared as mentioned above and incubated with ACSF containing $1.5 \mathrm{mg} / \mathrm{ml}$ sulfoNHS-LC-biotin (Pierce, Rockford, IL) for 45 min on ice. Cultures were rinsed in ACSF to quench the biotin reaction and lysed in $300 \mu \mathrm{l}$ of modified RIPA buffer [containing 1\% Triton X-100, 0.1\% SDS, $0.5 \%$ deoxycholic acid, and (in $\mathrm{mm}$ ): $50 \mathrm{NaPO}_{4}, 150$ $\mathrm{NaCl}, 2 \mathrm{NaF}, 10$ sodium pyrophosphate, and 1 PMSF plus $1 \mathrm{mg} / \mathrm{ml}$ leupeptin]. The homogenates were centrifuged at $14,000 \times g$ for $15 \mathrm{~min}$ at $4^{\circ} \mathrm{C}$, and the supernatant was harvested. After the measurement of protein concentration, $20 \mu \mathrm{g}$ of the supernatant was removed to measure total NR2A, NR2B, or GluR1. Then 200 $\mu \mathrm{g}$ of the supernatant was incubated with 100 $\mu \mathrm{l}$ of $50 \%$ NeutrAvidin-agarose (Pierce) for 3 hr at $4^{\circ} \mathrm{C}$ and washed three times with RIPA buffer. Biotinylated proteins were resuspended in $40 \mu \mathrm{l}$ of SDS sample buffer and boiled. Quantitative Western blots were performed on both total and biotinylated (surface) proteins with antiNR2A, anti-NR2B, and anti-GluR1 antibodies as described above. The surface/total ratio was calculated.

Cross-linking experiments were performed as previously described (Clayton et al., 2002; Grosshans et al., 2002). In brief, transverse spinal slices $(400 \mu \mathrm{m})$ from adult wild-type $(n=5)$ and PSD-93 knock-out $(n=5)$ mice ( $10-12$ weeks) were prepared as mentioned above and recovered by perfusion for $1 \mathrm{hr}$. Then the slices were placed into either ice-cold ACSF or cold ACSF containing $1 \mathrm{mg} / \mathrm{ml} \mathrm{BS}^{3}$ [bis-(sulfosuccinimidyl) suberate, Pierce] for $45 \mathrm{~min}$ at $4^{\circ} \mathrm{C}$. Four slices per control or treatment group were included for each animal. To quench the remaining $\mathrm{BS}^{3}$, we washed the slices three times in cold ACSF containing $20 \mathrm{~mm}$ Tris, $\mathrm{pH}$ 7.6. After homogenization the protein concentrations were determined. Surface expression was determined after semiquantitative Western blot analysis and after a comparison of treated samples with nontreated

\section{controls.}

Figure 1. Expression and localization of PSD-93 in the major pain-related regions of the CNS. A, RT-PCR analysis showed that a 571 bp product from PSD-93 was highly detected in the dorsal horn (DH) of spinal cord and forebrain (FB), whereas the mRNA was detected very weakly or not detected in the ventral horn (VH) of spinal cord and dorsal root ganglion (DRG). PCR product was cloned directly into the TA cloning vector and verified as PSD-93 by automatic DNA sequencing. $\beta$-Actin mRNA was used as a loading control. $B$, Western blot analysis showed that PSD-93 protein was expressed abundantly in the PSD fraction of the forebrain and dorsal horn, weakly in ventral horn, and not detected in the dorsal root ganglion. Tubulin was used as a loading control. C, PSD-93 immunoreactivity was distributed mainly in the superficial dorsal horn of wild-type (WT) mice. There was no immunostaining with the PSD-93 antibody in the dorsal horn of PSD-93 knock-out (KO) mice. Scale bar, $125 \mu \mathrm{m}$. D, The subcellular localization of PSD-93 in the superficial laminas of dorsal horn (DH) and the anterior cingular cortex (CO) of forebrain. Immunogold labeling of PSD-93 was localized most commonly in the postsynaptic membrane (arrows). Pr, Presynaptic; Po, postsynaptic. Scale bar, $0.2 \mu \mathrm{m}$. 


\section{Results}

PSD-93 expression and its interaction with NMDARs in the spinal cord and forebrain

We first examined the expression of PSD-93 messenger RNA and protein in the pain-related regions of the nervous system. RNA extracted from the dorsal root ganglion, spinal cord, and forebrain was probed by reverse transcriptase-PCR (RT-PCR) analysis. The PCR product was highly detected in the dorsal horn of spinal cord and forebrain areas (Fig. $1 A$ ). In contrast, it was detected very weakly or not at all in the ventral horn of spinal cord and dorsal root ganglion (Fig. $1 A$ ). The PCR product then was cloned directly into the pCR2.1-TOPO vector and verified as PSD-93 by automatic DNA sequencing. Immunoblot analysis further revealed abundant PSD-93 protein expression in the dorsal horn of spinal cord and forebrain areas, but not in the ventral horn of spinal cord or dorsal root ganglion (Fig. $1 \mathrm{~B}$ ). Using immunocytochemistry, we found that PSD-93 immunoreactivity occurred at a higher density in the superficial laminas and at a lower density in other laminas of spinal dorsal horn (Fig. $1 C$ ) and in the ventral horn. Moreover, the density of PSD-93 immunoreactivity in the superficial laminas was unaffected after unilateral sectioning of spinal dorsal nerve root or bilateral dorsolateral fasciculi lesions. Finally, we characterized the subcellular localization of PSD-93 under electron microscopy. In sections of the superficial dorsal horn or the anterior cingular cortex of forebrain, immunogold labeling with a PSD-93 antibody was associated with the postsynaptic membrane in neuronal synapses (Fig. 1D). These findings indicate that PSD-93 in the superficial dorsal horn and anterior cingular cortex, to a great extent, is intrinsic to these areas.

The NMDAR subunits including NR2A and NR2B are expressed in the neurons of the cortex and the superficial dorsal horn (Yung, 1998; Sun et al., 2000; Hagemann et al., 2003). Under electron microscopy, immunogold labeling with an NR1 or NR2A/2B antibody was associated with the postsynaptic membrane in the superficial dorsal horn and the anterior cingular cortex of forebrain (Fig. $2 A$ ). In the spinal dorsal horn the distribution of PSD-93 is similar to that of NR2A/2B (Fig. $2 B$ ). These data indicate that PSD-93 might colocalize and interact with the NMDARs in these areas. Indeed, in sections from these areas labeled with both PSD-93 and NR2A/2B antibodies, neuronal synapses showed labeling for both antibodies interspersed along the postsynaptic membrane (Fig. 2C). This was confirmed further with the use of coimmunoprecipitation, showing that PSD-93 antibody was able to immunoprecipitate not only itself but also NR2A and NR2B in the postsynaptic density fraction from the dorsal horn and forebrain (Fig. 2D). However, NR2A and NR2B could not be immunoprecipitated when PSD-93 antibody was preincubated with excess PSD-93 fusion protein (Fig.
C

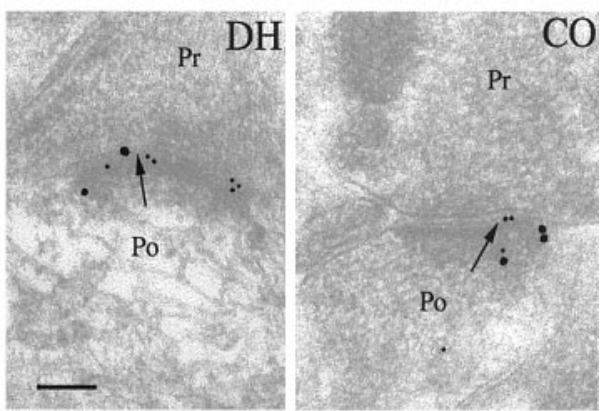

D
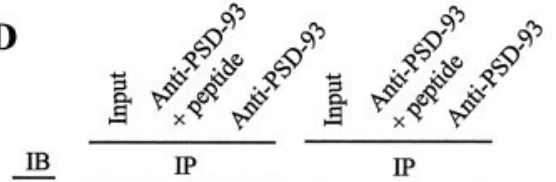

IP

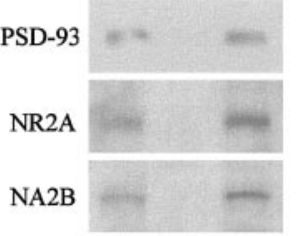

Spinal cord

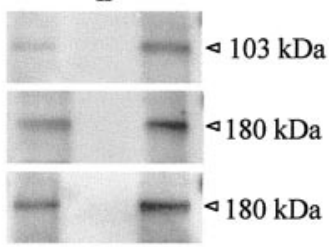

Forebrain

Figure 2. Identification of a complex assembled by PSD-93 and NMDARs in the spinal cord and forebrain. $A$, The subcellular localization of NR1 in the superficial laminas of dorsal horn (DH) and that of NR2A/2B in the anterior cingular cortex (CO) of forebrain. Immunogold labeling of NR1 in postsynaptic structures in the superficial laminas was associated almost exclusively with , and NR2B could not be immunoprecipitated when PSD-93 antibody was preincubated with the PSD-93 fusion protein. The amount of sample loaded for the input was $10 \%$ of that for the immunoprecipitation. IB, Immunoblotting.

2D). PSD-93 was not immunoprecipitated with a glutamate receptor 1 (GluR1; an AMPA receptor subunit) antibody (data not shown). As a molecular scaffold protein, PSD-93 targets and clusters NR2A and NR2B to synapses (Brenman et al., 1996; Kim et al., 1996). PSD-93 interaction with NMDARs at the synapses in these two regions suggests that PSD-93 might be required for surface NMDAR expression.

\section{PSD-93 deletion alters surface NR2A and NR2B expression}

PSD-93 mainly binds to the C termini of NMDAR subunits NR2A and NR2B (Brenman et al., 1996; Kim et al., 1996). The expression of NR2A and NR2B in total extracts of the spinal cord and forebrain was examined. Western blotting revealed that the expression of total NR2A or NR2B in the spinal cord as well as in the forebrain of knock-out mice was similar to that in wild-type or heterozygous mice (Fig. 3A). Immunocytochemistry showed that the staining density and localization of NR2A/2B immunoreactivity in the spinal cord of knock-out mice were similar to those in wild-type mice (Fig. $3 B$ ). We further compared the surface expression of NR2A and NR2B in cultured spinal dorsal horn neurons of wild-type and PSD-93 knock-out mice (McGee et al., 2001). The surface receptors were labeled with biotin and then precipitated. The ratio of surface to total NR2A or NR2B was determined by quantitative Western blotting. The biochemical analysis showed that surface NR2A and NR2B in knock-out mice 
A

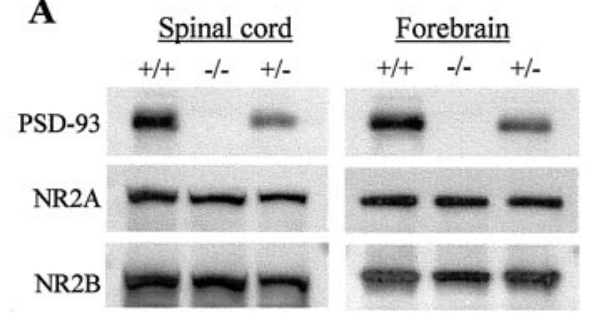

B

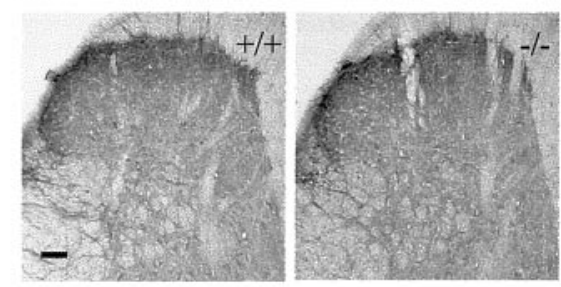

C
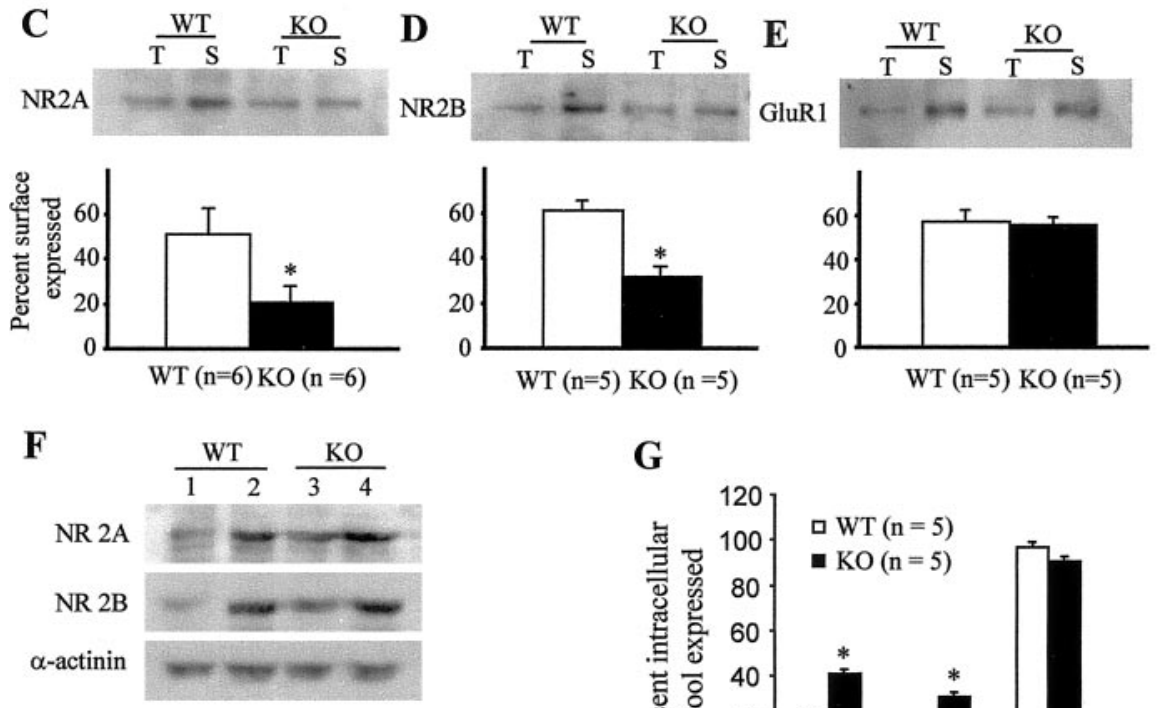

Lanes 1 and 3: slices with treatment $\mathrm{BS}^{3}$ Lanes 2 and 4: slices without treatment $\mathrm{BS}^{3}$

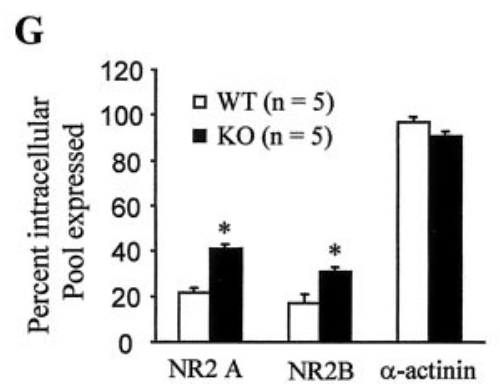

Figure 3. Expression of NR2A and NR2B in the spinal cord and forebrain of PSD-93 knock-out mice. A, Immunoblots of PSD-93, $N R 2 A$, and NR2B proteins in total extracts of spinal cord and forebrain of wild-type $(+/+)$, heterozygous $(+/-)$, and knock-out $(-/-)$ mice. PSD-93 protein is undetectable in knock-out mice. There was no significant difference in the density of NR2A or NR2B bands among wild-type, heterozygous, and knock-out mice ( $p>0.05 ; n=5$ for each group). Tubulin was used as a loading control (data not shown). $B$, The expression and distribution of NR2A/2B immunoreactivity in the spinal cord of wild-type $(+/+)$ and PSD-93 knock-out (-/-) mice. The density and localization of NR2A/2B immunoreactivity in the spinal cord of wild-type mice are similar to those in knock-out mice. Scale bar, $50 \mu \mathrm{m}$. C $-E$, Effect of PSD-93 deletion on surface NR2A and NR2B expression in the cultured neurons of spinal dorsal horn. The amount of sample loaded for the total (T) was $10 \%$ of that for the surface (S).C, The top panel depicts a representative Western blot that shows samples of total and biotinylated surface NR2A in wild-type (WT) and PSD-93 knock-out (KO) mice. The bottom panel shows the statistical summary of the densitometric analysis. Average surface NR2A levels in knock-out mice were reduced by $64 \%$ of the value in wild-type mice $\left({ }^{*} p<0.05\right)$. D, The top panel depicts a representative Western blot that shows samples of total and biotinylated surface NR2B in wild-type (WT) and PSD-93 knock-out (KO) mice. The bottom panel shows the statistical summary of the densitometric analysis. Average surface NR2B levels in knock-out mice were reduced by $50 \%$ of the value in wild-type mice $\left.{ }^{*} p<0.05\right)$. E, The top panel depicts a representative Western blot that shows samples of total and biotinylated surface GluR1 in wild-type (WT) and PSD-93 knock-out (KO) mice. The bottom panel shows the statistical summary of the densitometric analysis. There was no significant difference in surface GluR1 expression between wild-type and knock-out mice ( $p>0.05)$. F, G, Effect of PSD-93 deletion on surface NR2A and NR2B expression in the spinal cord neurons from adult mice. Surface expression was assayed by using a membrane-impermeable cross-linking agent $\left(\mathrm{BS}^{3}\right)$. The cross-linked product is unable to enter polyacrylamide gels, so only the intracellular pool is resolved by Western blotting. Changes in surface expression are detected by observing changes in this indirectly detected intracellular pool. $F$, A representative Western blot that shows samples of total and intracellular NR2A, NR2B, and $\alpha$-actinin, respectively, in the untreated control and BS ${ }^{3}$ treated groups of wild-type (WT) and PSD-93 knock-out (KO) mice. G, The statistical summary of the densitometric analysis. Average percentages of intracellular NR2A and NR2B levels in knock-out (KO) mice were increased by 190 and 194\%, respectively, of the value in wild-type (WT) mice ( ${ }^{*} p<0.05$ ). In contrast, the average percentage of intracellular $\alpha$-actinin level in knock-out mice was decreased by $0.92 \%$ of the value in wild-type mice.

were reduced by 64 and 50\%, respectively, of the value in wildtype mice, although total cellular NR2A and NR2B protein remained similar (Fig. 3C,D). To rule out the possibility of nonspecific changes in the postsynaptic neurons, we also monitored change of surface GluR1. In contrast to the effect on NR2A and NR2B, the deficiency of PSD-93 had no effect on surface GluR1 expression (Fig. 3E). Finally, we defined the surface expression of
NR2A and NR2B in adult spinal cord neurons by using a membrane-impermeable cross-linking reagent $\left(\mathrm{BS}^{3}\right)$, which crosslinks proteins only on the surface of cells (Clayton et al., 2002; Grosshans et al., 2002). Because the cross-linked product is unable to enter polyacrylamide gels, the intracellular pool of receptor was measured directly. Equal amounts of total protein were loaded so that changes in surface expression were reflected in alteration in the levels of intracellular proteins. As shown in Figure 3, $F$ and $G$, a significant decrease was seen in surface expression of spinal cord NR2A and NR2B of PSD-93 knock-out mice compared with that in wild-type mice ( $n=5$ in each case; $p<0.05)$, which confirmed the results obtained from the cultured spinal neurons described above. As a control, the expression of an uncross-linked intracellular protein, $\alpha$-actinin, in the spinal cord of PSD93 knock-out mice was similar to that in wild-type mice (Fig. 3F,G). Thus PSD-93 deletion specifically affects surface NR2A and NR2B expression. This might alter NMDAR-mediated excitatory postsynaptic function.

\section{PSD-93 deletion reduces NMDAR- mediated postsynaptic function}

To test directly the possibility that PSD-93 deletion alters postsynaptic NMDAR function, we measured mEPSCs in cultured spinal dorsal horn neurons of PSD-93 knock-out mice. mEPSCs were best described by a dual-exponential function when individual events were aligned by their fast rising peak and subsequently were averaged. This is typical of mEPSCs mediated by vesicular glutamate release (Bekkers and Stevens, 1989). The addition of $100 \mu \mathrm{M} \mathrm{AP-5}$ to the extracellular solution completely abolished the slow exponential (Fig. 4A), whereas the addition of AP-5 and NBQX (100 $\mu \mathrm{M})$ inhibited all mEPSCs. Therefore, the slower of the two exponentials was considered a result of NMDAR activation and the faster AMPAR activation. Most mEPSCs from neurons of wild-type mice had obvious NMDAR components (Fig. $4 B$ ). In contrast, neurons from knock-out mice exhibited less obvious and sometimes absent NMDAR responses (Fig. $4 B$ ). When individual events were averaged, the NMDAR component from knock-out mice was reduced greatly (11.28 \pm $1.02 \mathrm{pA}, n=21$ for wild type; $7.21 \pm 1.56 \mathrm{pA}, n=19$ for knockout; $p<0.005$ ) (Fig. $4 C, D$ ). As expected, the peak AMPA currents $(46.68 \pm 3.20 \mathrm{pA}, n=21$ for wild type; $44.36 \pm 1.10 \mathrm{pA}, n=$ 19 for knock-out), NMDA decay times (55.86 $\pm 8.52 \mathrm{msec}, n=$ 21 for wild type; $54.46 \pm 5.58 \mathrm{msec}, n=19$ for knock-out), and AMPA decay times $(1.75 \pm 0.13 \mathrm{msec}, n=21$ for wild type; 
A

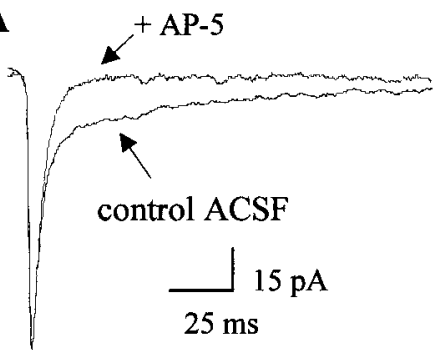

B

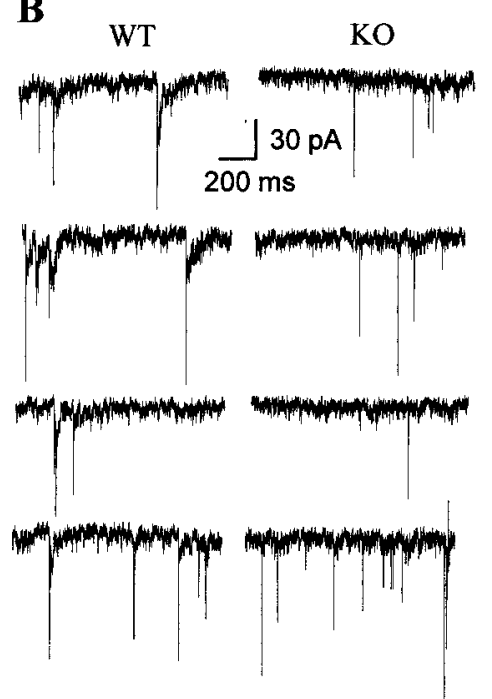

C

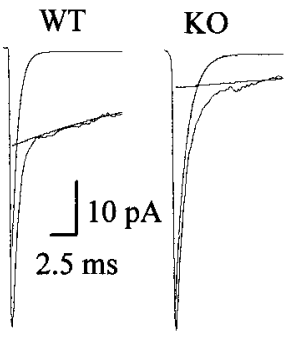

D
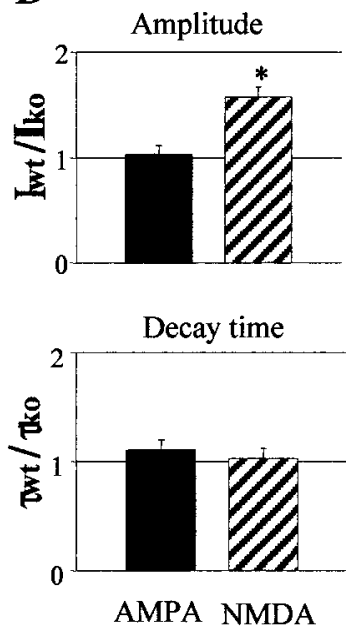

Figure 4. PSD-93 deletion reduced NMDAR-mediated mEPSCs from the cultured neurons of spinal dorsal horn. $A$, mEPSCs were acquired in the presence or absence of $100 \mu \mathrm{M} A \mathrm{P}-5$. The addition of $100 \mu \mathrm{m} \mathrm{AP-5}$ to the extracellular solution abolished the slow exponential, whereas the addition of AP-5 plus NBQX (100 $\mu \mathrm{m})$ completely blocked miniature events. One hundred events were selected before (control ACSF) and during AP-5 perfusion. After AP-5 perfusion the decay time of the fast component was not altered significantly (before AP-5, $\tau_{\text {fast }}=1.98 \pm$ $0.20 \mathrm{msec}$; during AP-5, $\left.\tau_{\text {fast }}=1.96 \pm 0.19 \mathrm{msec} ; n=20\right)$. Therefore, the amplitude of the second exponential was taken as the NMDAR peak current. The amplitude of the averaged $\mathrm{mEPSC}$ was taken as the peak AMPA current. $B$, Four consecutive $1 \mathrm{sec}$ traces from a cultured neuron representative of wild-type (WT) or PSD-93 knock-out (KO) mice. C, Trace averages from the neurons illustrated in $B$. Selected from each neuron were 120 events, and the responses were aligned by their peaks. The neurons in wild-type and knock-out mice were fit by a doubleexponential function, and their individual components were displayed. D, The top plot compares the average current ratio for NMDARs and AMPA receptors between pooled wild-type and knock-out mice responses $\left({ }^{*} p<0.005\right)$. The bottom plot compares the ratio of decay times for the AMPA receptors and NMDARs between pooled wild-type and knock-out mice responses.

$1.96 \pm 0.15 \mathrm{msec}, n=19$ for knock-out) were not significantly different (Fig. 4C,D). In addition, mEPSC frequency $(0.721 \pm$ $0.11 \mathrm{~Hz}, n=21$ for wild type; $0.561 \pm 0.05 \mathrm{~Hz}, n=19$ for knock-out), average input resistance $(373.1 \pm 27.6 \mathrm{M} \Omega, n=21$ for wild type; $375.9 \pm 26.32 \mathrm{M} \Omega, n=19$ for knock-out), and series resistance $(17.42 \pm 0.532 \mathrm{M} \Omega, n=21$ for wild type; $18.05 \pm 0.586 \mathrm{M} \Omega, n=19$ for knock-out) for each culture genotype were not changed statistically. These data indicate that the deficiency of PSD-93 does affect NMDAR-mediated postsynaptic function while having little effect on AMPA receptor function.

To observe further the effect of PSD-93 deletion on NMDARmediated postsynaptic function, we recorded intracellular EPSPs in the spinal cord slices from adult knock-out mice. EPSPs in the superficial dorsal horn neurons were evoked by dorsal root stimulation (Wei et al., 2001). After blockade of AMPA and kainate receptors by CNQX $(20 \mu \mathrm{M})$, we observed a slow EPSP that could be blocked completely and reversibly by a selective NMDAR an-

tagonist, AP-5 (100 $\mu \mathrm{M}$; Fig. 5A). To enhance sensitivity in NMDAR-mediated EPSPs, we injected current through the recording electrode to depolarize neurons and relieve any voltagedependent $\mathrm{Mg}^{2+}$ blockade at a holding potential of $-50 \mathrm{mV}$. Slow EPSP slopes in knock-out mouse slices were reduced significantly as compared with wild-type mouse slices (Fig. 5A). In contrast, fast AMPA and kainate receptor-mediated EPSPs were similar in spinal cord slices of wild-type mice $(5.17 \pm 0.29 \mathrm{mV} /$ msec; $n=20)$ and knock-out mice $(4.94 \pm 0.77 \mathrm{mV} / \mathrm{msec} ; n=$ 25). Resting neuronal membrane potentials were not different in wild-type $(-68.9 \pm 2.7 \mathrm{mV} ; n=20)$ and knock-out mouse $(-69.5 \pm 2.7 \mathrm{mV} ; n=25)$ slices.

We also examined NMDAR-mediated postsynaptic function in the neurons of the anterior cingular cortex. We prepared brain slices from adult mice and recorded field EPSPs (fEPSPs) after local electron stimulation (Sah and Nicoll, 1991). Consistent with the findings above in the dorsal horn, slow AP-5-sensitive fEPSPs, isolated in the presence of CNQX $(20 \mu \mathrm{M})$, were decreased dramatically in the anterior cingular cortex neurons of PSD-93 knock-out mice (Fig. 5B). To test further whether alteration in NMDAR-mediated postsynaptic function also appears in other regions of forebrain, we recorded fEPSPs in the insular cortex. As before, knock-out mice, compared with wild-type mice, displayed reduced NMDAR-mediated fEPSP in the neurons of this area (Fig. 5B). No significant changes in AMPAR-mediated fEPSP were observed in either region of forebrain (data not shown). These findings provide evidence that PSD-93 deletion influences NMDAR-mediated postsynaptic response in the spinal cord dorsal horn and forebrain of adult mice.

PSD-93 deletion reduces NMDAR-dependent persistent pain The spinal cord dorsal horn and forebrain are major pain-related regions in the nervous system. We next asked whether the reduction of surface NMDAR expression and its synaptic function by PSD-93 deletion affected the animals' behavioral responses to acute noxious stimuli or peripheral inflammation/nerve injury. Both male and female mice were viable and fertile, with normal appearance and locomotor activity (McGee et al., 2001). We first examined baseline responses of knock-out mice to mechanical or thermal stimulation. The different intensities of von Frey monofilaments (mechanical stimuli) and high-intensity radiant heat (thermal stimulus) were applied to the plantar sides of both hind paws. No significant differences in paw withdrawal latencies (in response to thermal stimulus) or frequencies (in response to mechanical stimuli) were observed among wild-type, heterozygous, and knock-out mice (Fig. 6A,B). This indicates that acute nociceptive transmission is not altered significantly in knock-out mice. We then studied an inflammatory pain model produced by hind paw injection of CFA. Subcutaneous injection of CFA produces long-lasting inflammation and long-term mechanical pain hypersensitivity. In wild-type mice the application of both 0.24 $\mathrm{mN}$ (low intensity) and $4.33 \mathrm{mN}$ (moderate intensity) von Frey filaments to the dorsum of the injected hind paw elicited significant mechanical pain hypersensitivity, which appeared on the first day after CFA injection and persisted for $9 \mathrm{~d}$ or longer (Fig. $6 C, D)$. In contrast to the wild-type mice, there were no differences in paw withdrawal frequencies in response to mechanical stimuli in PSD-93 knock-out mice as compared to baseline (Fig. $3 C, D)$. No obvious difference in the degree of hind paw edema was found at day 9 between wild-type (paw thickness, $2.77 \pm 0.07$ $\mathrm{mm} ; n=10)$ and PSD-93 knock-out $(2.54 \pm 0.11 ; n=10)$ mice ( $p>0.05$, Student's $t$ test). We also determined the possible role of PSD-93 in neuropathic pain, a common cause of chronic pain 
$\mathbf{A}$

Dorsal horn

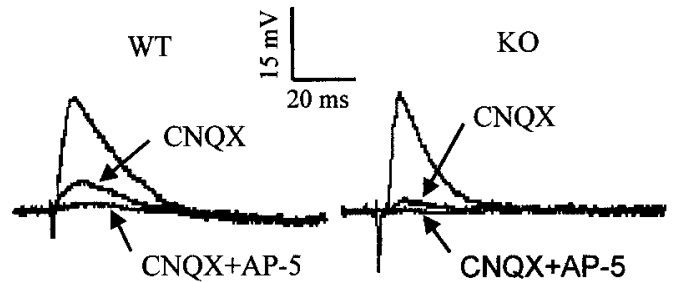

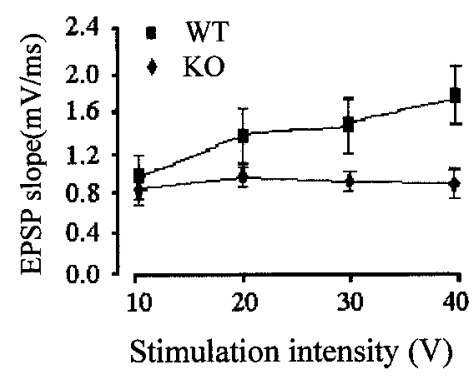

B

Anterior cingular cortex

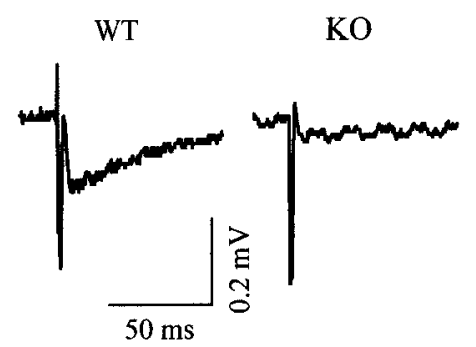

Anterior cingular cortex

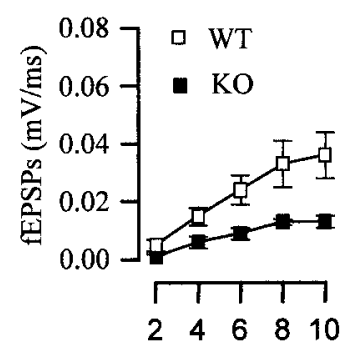

Insular cortex

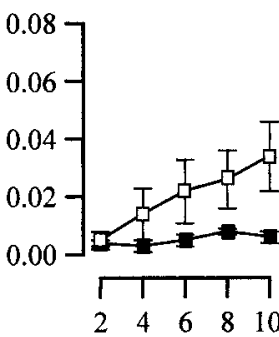

Stimulation intensity $(x 10 \mathrm{~V})$

Figure 5. PSD-93 deletion attenuated NMDAR-mediated excitatory postsynaptic responses. $A$, Traces of EPSPs recorded in the presence or absence of CNQX (20 $\mu \mathrm{m})$ or CNQX and AP-5 $(100 \mu \mathrm{m})$ from the neurons of the superficial dorsal horn in adult wild-type (WT) and knock-out (KO) mice. Slow NMDAR-mediated synaptic responses were compared at four dorsal root stimulation intensities $(10,20,30$, and $40 \mathrm{~V})$, revealing significant differences between wild-type $(n=6-8)$ and knock-out mice $(n=8-10 ; p<$ 0.05). $B$, Traces of NMDAR-mediated fEPSPs recorded in the presence of $20 \mu \mathrm{m}$ CNQX from the anterior cingular cortex of forebrain in adult wild-type (WT) and knock-out (KO) mice. Similar traces also were found in insular cortex of forebrain (data not shown). NMDAR-mediated synaptic responses were compared at four stimulation intensities $(40,60,80$, and $100 \mathrm{~V})$ in the anterior cingular cortex (WT, $n=8 ; \mathrm{KO}, n=10$ ) and insular cortex (WT, $n=8 ; \mathrm{KO}, n=10$ ), revealing significant differences between wild-type and knock-out mice $(p<0.05)$.

treated in clinical practice. We tightly ligated the fifth lumbar spinal nerve root and then completely transected it just distal to the ligature in wild-type and knock-out mice. This nerve injury produces a persistent pain syndrome characterized by a significant and long-lasting increase in paw withdrawal frequency to mechanical stimulation on the injured side (Kim and Chung, 1992; Mansikka et al., 2000). In the wild-type mice the mechanical response frequencies to both 0.24 and $4.33 \mathrm{mN}$ mechanical stimuli were increased significantly by the second day after spinal nerve injury. This increased responsiveness persisted for $14 \mathrm{~d}$ or longer (Fig. 6E,F). The PSD-93 knock-out mice showed only modest increases in response frequencies to low-intensity mechanical stimuli after surgery (Fig. $6 E$ ). However, the magnitude of the change in the knock-out mice was much less than what we recorded in the wild-type mice (Fig. 6E). Moreover, the knockout mice exhibited no significant increases in withdrawal frequency in response to moderate-intensity mechanical stimulation after spinal nerve injury (Fig. $6 F$ ). Withdrawal frequencies on the contralateral side essentially were unchanged after CFA injection and after nerve injury (data not shown).

Consistent with the previous studies (Ren et al., 1992; Mao et al., 1993; Chaplan et al., 1997; Jasmin et al., 1998), intrathecal NMDA receptor antagonist MK-801 significantly attenuated CFA-or nerve injury-induced mechanical hyperalgesia on the ipsilateral side, without detectable effect on the behavioral responses on the contralateral side, in wild-type mice. On day 3 , when CFA-induced mechanical hyperalgesia was near peak se- verity, MK-801 injection (1.0 nmol) reduced the ipsilateral/contralateral differences in paw withdrawal frequencies to $24.4 \pm 2.7 \%$ (in response to $0.24 \mathrm{mN}$ ) and $27.5 \pm 6.1 \%$ (in response to $4.33 \mathrm{mN}$ ) of predrug differences $(n=5 ; p<0.05)$. Similarly, the ipsilateral/contralateral differences in paw withdrawal frequencies on postnerve injury day 6 (when mechanical hyperalgesia reached the peak) were reduced by intrathecal administration of MK-801 32.3 $\pm 1.5 \%$ (in response to 0.24 $\mathrm{mN}$ ) and $18.5 \pm 3.6 \%$ (in response to 4.33 $\mathrm{mN})$ of predrug differences $(n=6 ; p<$ $0.05)$. In contrast, paw withdrawal responses of PSD-93 knock-out mice (which exhibited blunted responses to mechanical stimuli as described above) were unchanged by intrathecal administration of MK-801. The equivalent values were $95.2 \pm 2.3 \%(0.24 \mathrm{mN})$ and $91.8 \pm$ $4.1 \%(4.33 \mathrm{mN})$ for the CFA model $(n=$ $5 ; p>0.05)$ and $93.4 \pm 4.2 \%(0.24 \mathrm{mN})$ and $90.7 \pm 3.2 \%(4.33 \mathrm{mN})$ for the nerve injury model $(n=6 ; p>0.05$ in each case), respectively. Taken together with the observations above, these results indicate that the deficiency of PSD-93 reduces NMDAR-dependent persistent pain.

\section{Discussion}

The current work provides strong genetic evidence that the deficiency of PSD-93 protein reduces NMDAR synaptic function and associated persistent pain by the mechanism of surface NMDAR alteration. PSD-93 seems to be similar to another PDZ domain protein, Drosophila disc-large protein (DLG), the mutants of which altered localization and function of Shaker type $\mathrm{K}^{+}$channels (Tejedor et al., 1997). Our study is the first identification of an interacting protein required for normal synaptic NMDAR function and its dependent pain signaling in the vertebrate CNS. PSD-93 may play an important role in coupling NMDAR activation to central pain signaling.

Under normal conditions NMDARs are expressed stably in the postsynaptic membrane (Luscher et al., 1999; Ehlers, 2000; Lin et al., 2000). However, recent experimental evidence demonstrates that the surface expression of NMDARs is regulated tightly. For example, long-term potentiation leads to rapid surface expression of NMDARs (Grosshans et al., 2002), whereas metabotropic glutamate receptor-stimulated long-term depression produces rapid internalization, that is, loss of NMDARs from synapses (Snyder et al., 2001). Furthermore, the internalization of NMDARs is determined by the $\mathrm{C}$ terminus of NR2B (Roche et al., 2001). PSD-95, which binds to the C-terminal binding motif of NR2, inhibits NR2B-mediated internalization, and the deletion of the PDZ-binding domain of NR2B increases internalization in neurons (Roche et al., 2001). We found that genetic deletion of PSD-93 resulted in the reduction of surface NR2A and NR2B expression in spinal dorsal horn neurons. These results indicate that surface expression of NMDARs (at least NR2A and NR2B subunits) could be regulated by the C-terminal motif-binding PDZ proteins. 
The change of NMDAR expression on synaptic membranes influences NMDARmediated synaptic function and associated pain signaling. Transgenic mice that overexpress NR2B on central neurons displayed not only enhanced NMDARmediated synaptic response but also enhanced pain responsiveness to peripheral inflammation (Wei et al., 2001). In vitro coexpression of PSD-95 protein with NMDA receptors increased surface expression and channel-opening rates of NMDA receptors (Carroll and Zukin, 2002). Our study demonstrated that targeted disruption of the PSD-93 gene reduced not only surface NR2A and NR2B expression but also NMDAR-mediated EPSCs in spinal dorsal horn neurons. Moreover, PSD-93 knock-out mice exhibited blunted NMDAR-mediated excitatory postsynaptic responses and dependent persistent pain. Interestingly, the mice with mutant PSD-95 protein displayed normal synaptic NMDAR expression and NMDAR-mediated EPSCs in hippocampal neurons, although they showed altered long-term potentiation and impaired learning (Migaud et al., 1998). The reason for the discrepancy between these two transgenic mice is unclear but may be related to the targeted sites of PDZ domains. The coding sequence of the second PDZ domain of PSD-93 is deleted completely in PSD-93 knock-out mice (McGee et al., 2001), whereas PSD-95 transgenic mice carry a targeted mutation in the PSD-95 gene that leaves the first two PDZ domains intact by introducing a stop codon into the third PDZ domain and replacing downstream sequences with an internal ribosome entry site (Migaud et al., 1998). The second PDZ domain of PSD-95 and PSD-93 is critical for binding and anchoring of NMDARs at synaptic membrane. The deletion of the second PDZ domain of PSD-95 or PSD-93 not only disrupts interaction between NMDARs and PSD-95 or PSD-93 but also reduces NMDAR clustering at cellular membranes (Kornau et al., 1995; Brenman et al., 1996; Kim et al., 1996). That the first two PDZ domains were not de-

tected in synaptosome subfractions of PSD-95 mutant mice might be related to the specificity of the antibody, because this antibody also did not detect the first two PDZ domains of fulllength PSD-95 in synapto some subfractions of wild-type mice (Migaud et al., 1998). Thus with the use of a suitable antibody the first two PDZ domains may be detected in synaptosome subfractions of PSD-95 mutant mice. These two PDZ domains may be involved in maintaining normal synaptic localization and postsynaptic function of NMDARs in PSD-95 mutant mice. We also found that PSD-93 deletion did not affect significantly the surface AMPA receptor expression or AMPA receptor-mediated
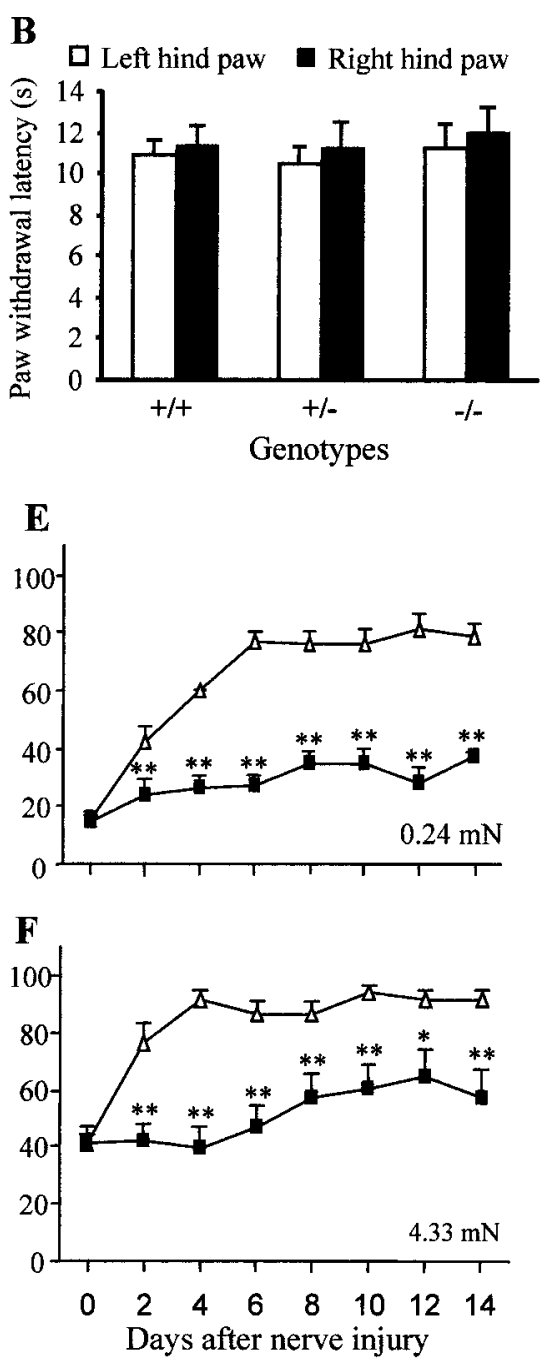

Figure 6. Role of PSD-93 in pain behavioral responses. A, Baseline response frequencies of paw withdrawal to mechanical stimulation that were elicited by various forces of von Frey monofilaments in intact mice. Withdrawal frequencies were similar in wild-type $(+/+)$, heterozygous $(+/-)$, and knock-out $(-/-)$ mice $(n=15$ for each group). $B$, Baseline withdrawal latency in response to thermal stimulation that was elicited by high-intensity radiant heat applied to the plantar sides of left and right hind paws in intact mice. Thermal thresholds of knock-out mice were not different from those of wild-type or heterozygous mice $(n=$ 12 for each group). C, D, Effect of PSD-93 deletion on (FA-induced inflammatory pain. CFA produced a significant increase in paw al frequencies in response to $0.24 \mathrm{mN}$ (low intensity) and $4.33 \mathrm{mN}$ (moderate intensity) mechanical stimuli on the injured side in wild-type (WT) mice (repeated measures ANOVA, $p<0.001 ; n=5)$, but not in knock-out (K0) mice ( $p>0.05 ; n=5$ ) Asterisks indicate a significant difference on the injured side between wild-type and knock-out mice $\left({ }^{*} p<0.05\right.$ and ${ }^{* *} p<0.01$, crease in paw withdrawal frequencies to 0.24 and $4.33 \mathrm{mN}$ mechanical stimuli on the injured side ( $p<0.0001 ; n=14$ for each group). 列 exhibited a modest but significant mechanical hypersensitivity in response to low-intensity mechanical stimulation on days 8,10 , and 14 after surgery $(E ; p<0.01)$, but not to moderate-intensity mechanical stimulation $(F ; p>0.05)$.

postsynaptic function in the neurons of the spinal cord and forebrain cortex. This result is inconsistent with recent in vitro studies in which the expressional alteration or palmitoylation of the MAGUK proteins like PSD-95 regulates surface and synaptic AMPA receptor-mediated trafficking via stargazin, an AMPA receptor-interacting protein (Chen et al., 2000; El-Husseini et al., 2000, 2002; El-Husseini and Bredt, 2002; Schnell et al., 2002). It has been noted that synaptic targeting/insertion and synaptic stabilization of AMPA receptors may be mediated by several mechanisms. The delivery of AMPA receptors to synapses also is related to other clustering proteins such as GRIP/ABP or PICK1, 
which are important for synaptic targeting or synaptic surface accumulation of AMPA receptors (Sheng and Pak, 1999; Braithwaite et al., 2000; Garner et al., 2000; Osten et al., 2000; Barry and Ziff, 2002). We found that PSD-93 knock-out mice displayed normal GRIP/ABP and PICK1 expression in the spinal cord and forebrain (data not shown). It is very likely that these clustering proteins maintain normal surface AMPA receptor expression and its associated function in PSD-93 transgenic mice. This view is supported by other studies (Migaud et al., 1998; Hashimoto et al., 1999) showing that surface and synaptic AMPA receptor trafficking is intact in hippocampal neurons of PSD-95 or stargazin mutant mice.

PSD-93 is homologous to three other neuronal MAGUKs, PSD-95, SAP102, and SAP97 (Kornau et al., 1997; Craven and Bredt, 1998; Garner et al., 2000), but PSD-93 has some unique characteristics. For example, both PSD-93 and PSD-95 are palmitoylated N-terminally, but, unlike PSD-95, palmitoylation is not necessary for the PSD-93 postsynaptic targeting (Firestein et al., 2000). In some regions of the CNS the expression and distribution of the four neuronal MAGUK proteins are different. In cerebellar Purkinje neurons only PSD-93 is expressed (McGee et al., 2001). We have reported that PSD-95 and SAP102 also are expressed in the spinal cord but are distributed mainly in lamina I and outer lamina II (Tao et al., 2000). SAP97 protein was undetectable in the PSD fraction of the spinal cord (data not shown). Compared with PSD-95 and SAP102, PSD-93 is expressed uniquely in inner lamina II of the spinal cord. It is well known that the postsynaptic neurons in inner lamina II differ considerably from those in lamina I and outer lamina II with respect to forming synaptic architecture with primary afferent terminals (Hunt et al., 1992; Chen et al., 1995). These results suggest that PSD-93, at least in the spinal dorsal horn, plays a distinct role in targeting of NMDARs to the synapses, which may not be compensated for completely by other related neuronal MAGUK proteins.

Our study implicates a molecular mechanism by which alteration of the expression of NMDAR-interacting proteins could modulate NMDAR-mediated synaptic function and behavioral responses. This might provide a potential novel biochemical target for the prevention and therapy of persistent pain.

\section{References}

Barry MF, Ziff EB (2002) Receptor trafficking and the plasticity of excitatory synapses. Curr Opin Neurobiol 12:279-286.

Basbaum AI, Woolf CJ (1999) Pain. Curr Biol 9:R429-R431.

Bekkers JM, Stevens CF (1989) NMDA and non-NMDA receptors are colocalized at individual excitatory synapses in cultured rat hippocampus. Nature 341:230-233.

Braithwaite SP, Meyer G, Henley JM (2000) Interactions between AMPA receptors and intracellular proteins. Neuropharmacology 39:919-930.

Brenman JE, Christopherson KS, Craven SE, McGee AW, Bredt DS (1996) Cloning and characterization of postsynaptic density-93, a nitric oxide synthase-interacting protein. J Neurosci 16:7407-7415.

Brenman JE, Topinka JR, Cooper EC, McGee AW, Rosen J, Milroy T, Ralston HJ, Bredt DS (1998) Localization of postsynaptic density-93 to dendritic microtubules and interaction with microtubule-associated protein 1A. J Neurosci 18:8805-8813.

Carroll RC, Zukin RS (2002) NMDA-receptor trafficking and targeting: implications for synaptic transmission and plasticity. Trends Neurosci 25:571-577.

Chaplan SR, Malmberg AB, Yaksh TL (1997) Efficacy of spinal NMDA receptor antagonism in formalin hyperalgesia and nerve injury-evoked allodynia in the rat. J Pharmacol Exp Ther 280:829-837.

Chen CC, Akopian AN, Sivilotti L, Colquhoun D, Burnstock G, Wood JN (1995) A P2X purinoceptor expressed by a subset of sensory neurons. Nature 377:428-431.
Chen L, Chetkovich DM, Petralia RS, Sweeney NT, Kawasaki Y, Wenthold RJ, Bredt DS, Nicoll RA (2000) Stargazin regulates synaptic targeting of AMPA receptors by two distinct mechanisms. Nature 408:936-943.

Cho K-O, Hunt CA, Kennedy MB (1992) The rat brain postsynaptic density fraction contains a homology of the Drosophila discs-large tumor suppressor protein. Neuron 9:929-942.

Clayton DA, Grosshans DR, Browning MD (2002) Aging and surface expression of hippocampal NMDA receptors. J Biol Chem 277:14367-14369.

Craven SE, Bredt DS (1998) PDZ proteins organize synaptic signaling pathways. Cell 93:495-498.

Cull-Candy S, Brickley S, Farrant M (2001) NMDA receptor subunits: diversity, development, and disease. Curr Opin Neurobiol 11:327-335.

Dougherty PM, Willis WD (1991) Enhancement of spinothalamic neuron responses to chemical and mechanical stimuli following combined micro-iontophoretic application of $N$-methyl-D-aspartic acid and substance P. Pain 47:85-93.

Ehlers MD (2000) Reinsertion or degradation of AMPA receptors determined by activity-dependent endocytic sorting. Neuron 28:511-525.

El-Husseini AD, Bredt DS (2002) Protein palmitoylation: a regulator of neuronal development and function. Nat Rev Neurosci 3:791-802.

El-Husseini AD, Schnell E, Chetkovich DM, Nicoll RA, Bredt DS (2000) PSD-95 involvement in maturation of excitatory synapses. Science 290:1364-1368.

El-Husseini AD, Schnell E, Dakoji S, Sweeney N, Zhou Q, Prange O, Gauthier-Campbell C, Aguilera-Moreno A, Nicoll RA, Bredt DS (2002) Synaptic strength regulated by palmitate cycling on PSD-95. Cell 108:849-863.

Fairbanks CA, Schreiber KL, Brewer KL, Yu CG, Stone LS, Kitto KF, Nguyen HO, Grocholski BM, Shoeman DW, Kehl LJ, Regunathan S, Reis DJ, Yezierski RP, Wilcox GL (2000) Agmatine reverses pain induced by inflammation, neuropathy, and spinal cord injury. Proc Natl Acad Sci USA 97:10584-10589.

Firestein BL, Craven SE, Bredt DS (2000) Postsynaptic targeting of MAGUKs mediated by distinct N-terminal domains. NeuroReport 11:3479-3484.

Follesa P, Ticku MK (1996a) NMDA receptor upregulation: molecular studies in cultured mouse cortical neurons after chronic antagonist exposure. J Neurosci 16:2172-2178.

Follesa P, Ticku MK (1996b) Chronic ethanol-mediated up-regulation of the $N$-methyl-D-aspartate receptor polypeptide subunits in mouse cortical neurons in culture. J Biol Chem 271:13297-13299.

Garner CC, Nash J, Huganir RL (2000) PDZ domains in synapse assembly and signaling. Trends Cell Biol 10:274-280.

Grosshans DR, Clayton DA, Coultrap SJ, Browning MD (2002) LTP leads to rapid surface expression of NMDA but not AMPA receptors in adult rat CA1. Nat Neurosci 5:27-33.

Hagemann G, Kluska MM, Redecker C, Luhmann HJ, Witte OW (2003) Distribution of glutamate receptor subunits in experimentally induced cortical malformations. Neuroscience 117:991-1002.

Hashimoto K, Fukaya M, Qiao X, Sakimura K, Watanabe M, Kano M (1999) Impairment of AMPA receptor function in cerebellar granule cells of ataxic mutant mouse stargazer. J Neurosci 19:6027-6036.

Hewitt DJ (2000) The use of NMDA-receptor antagonists in the treatment of chronic pain. Clin J Pain 16:S73-S79.

Hunt SP, Mantyh PW, Priestley JV (1992) The organization of biochemically characterized sensory neurons. In: Sensory neurons, diversity, development, and plasticity (Scott SA, ed), pp 60-76. New York: Oxford UP.

Jasmin L, Kohan L, Franssen M, Janni G, Goff JR (1998) The cold plate as a test of nociceptive behaviors: design and application to the study of chronic neuropathic and inflammatory pain models. Pain 75:367-382.

Kim E, Cho KO, Rothschild A, Sheng M (1996) Heteromultimerization and NMDA receptor-clustering activity of chapsyn-110, a member of the PSD-95 family of proteins. Neuron 17:103-113.

Kim SH, Chung JM (1992) An experimental model for peripheral neuropathy produced by segmental spinal nerve ligation in rat. Pain 50:355-363.

Kistner U, Wenzel BM, Veh RW, Cases-Langhoff C, Garner AM, Appeltauer U, Voss B, Gundelfinger ED, Garner CC (1993) SAP90, a rat presynaptic protein related to the product of the Drosophila tumor suppressor gene dlg-A. J Biol Chem 268:4580-4583.

Kornau H-C, Schenker LT, Kennedy MB, Seeburg PH (1995) Domain in- 
teraction between NMDA receptor subunits and the postsynaptic density protein PSD-95. Science 269:1737-1740.

Kornau H-C, Seeburg PH, Kennedy MB (1997) Interaction of ion channels and receptors with PDZ domains. Curr Opin Neurobiol 7:368-373.

Lau LF, Mammen A, Ehlers MD, Kindler S, Chung WJ, Garner CC, Huganir RL (1996) Interaction of the $N$-methyl-D-aspartate receptor complex with a novel synapse-associated protein, SAP102. J Biol Chem 271:21622-21628.

Lin JW, Ju W, Foster K, Lee SH, Ahmadian G, Wyszynski M, Wang YT, Sheng M (2000) Distinct molecular mechanisms and divergent endocytotic pathways of AMPA receptor internalization. Nat Neurosci 3:1282-1290.

Luscher C, Xia H, Beattie EC, Carroll RC, von Zastrow M, Malenka RC, Nicoll RA (1999) Role of AMPA receptor cycling in synaptic transmission and plasticity. Neuron 24:649-658.

Mansikka H, Sheth RN, DeVries C, Lee H, Winchurch R, Raja SN (2000) Nerve injury-induced mechanical but not thermal hyperalgesia is attenuated in neurokinin-1 receptor knock-out mice. Exp Neurol 162:343-349.

Mao J, Price DD, Hayes RL, Lu J, Mayer DJ, Frenk H (1993) Intrathecal treatment with dextrorphan or ketamine potently reduced pain-related behaviors in a rat model of peripheral mononeuropathy. Brain Res 605:164-168.

McGee AW, Topinka JR, Hashimoto K, Petralia RS, Kakizawa S, Kauer F, Aguilera-Moreno A, Wenthold RJ, Kano M, Bredt DS (2001) PSD-93 knock-out mice reveal that neuronal MAGUKs are not required for development or function of parallel fiber synapses in cerebellum. J Neurosci 21:3085-3091.

Migaud M, Charlesworth P, Dempster M, Webster LC, Watabe AM, Makhinson M, He Y, Ramsay MF, Morris RG, Morrison JH, O'Dell TJ, Grant SG (1998) Enhanced long-term potentiation and impaired learning in mice with mutant postsynaptic density-95 protein. Nature 396:433-439.

Mori H, Mishina M (1995) Structure and function of the NMDA receptor channel. Neuropharmacology 34:1219-1237.

Muller BM, Kistner U, Veh RW, Cases-Langhoff C, Becker B, Gundelfinger ED, Garner CC (1995) Molecular characterization and spatial distribution of SAP97, a novel presynaptic protein homologous to SAP90 and the Drosophila discs-large tumor suppressor protein. J Neurosci 15:2354-2366.

O’Brien RJ, Mammen AL, Blackshaw S, Ehlers MD, Rothstein JD, Huganir RL (1997) The development of excitatory synapses in cultured spinal neurons. J Neurosci 17:7339-7350.

Osten P, Khatri L, Perez JL, Kohr G, Giese G, Daly C, Schulz TW, Wensky A, Lee LM, Ziff EB (2000) Mutagenesis reveals a role for ABP/GRIP binding to GluR2 in synaptic surface accumulation of the AMPA receptor. Neuron 27:313-325.

Petralia RS, Wenthold RJ (1999) Immunocytochemistry of NMDA receptors. Methods Mol Biol 128:73-92.

Petralia RS, Wang YX, Wenthold RJ (1994) The NMDA receptor subunits NR2A and NR2B show histological and ultrastructural localization patterns similar to those of NR1. J Neurosci 14:6102-6120.

Ren K, Hylden JL, Williams GM, Ruda MA, Dubner R (1992) The effects of a non-competitive NMDA receptor antagonist, MK-801, on behavioral hyperalgesia and dorsal horn neuronal activity in rats with unilateral inflammation. Pain 50:331-344.

Roche KW, Ly CD, Petralia RS, Wang YX, McGee AW, Bredt DS, Wenthold RJ (1999) Postsynaptic density-93 interacts with the $\delta 2$ glutamate receptor subunit at parallel fiber synapses. J Neurosci 19:3926-3934.

Roche KW, Standley S, McCallum J, Dune Ly C, Ehlers MD, Wenthold RJ (2001) Molecular determinants of NMDA receptor internalization. Nat Neurosci 4:794-802.

Sah P, Nicoll RA (1991) Mechanisms underlying potentiation of synaptic transmission in rat anterior cingulate cortex in vitro. J Physiol (Lond) 433:615-630.

Sans N, Petralia RS, Wang YX, Blahos JII, Hell JW, Wenthold RJ (2000) A developmental change in NMDA receptor-associated proteins at hippocampal synapses. J Neurosci 20:1260-1271.

Schnell E, Sizemore M, Karimzadegan S, Chen L, Bredt DS, Nicoll RA (2002) Direct interactions between PSD-95 and stargazin control synaptic AMPA receptor number. Proc Natl Acad Sci USA 99:13902-13907.

Sheng M (1996) PDZs and receptor/channel clustering: rounding up the latest suspects. Neuron 17:575-578.

Sheng M, Pak DT (1999) Glutamate receptor anchoring proteins and the molecular organization of excitatory synapses. Ann NY Acad Sci 868:483-493.

Shi J, Aamodt SM, Constantine-Paton M (1997) Temporal correlations between functional and molecular changes in NMDA receptors and GABA neurotransmission in the superior colliculus. J Neurosci 17:6264-6276.

Snyder EM, Philpot BD, Huber KM, Dong X, Fallon JR, Bear MF (2001) Internalization of ionotropic glutamate receptors in response to mGluR activation. Nat Neurosci 4:1079-1085.

Sprengel R, Suchanek B, Amico C, Brusa R, Burnashev N, Rozov A, Hvalby O, Jensen V, Paulsen O, Andersen P, Kim JJ, Thompson RF, Sun W, Webster LC, Grant SG, Eilers J, Konnerth A, Li J, McNamara JO, Seeburg PH (1998) Importance of the intracellular domain of NR2 subunits for NMDA receptor function in vivo. Cell 92:279-289.

Sun L, Shipley MT, Lidow MS (2000) Expression of NR1, NR2A-D, and NR3 subunits of the NMDA receptor in the cerebral cortex and olfactory bulb of adult rat. Synapse 35:212-221.

Tao Y-X, Johns RA (2002) Activation and up-regulation of spinal cord nitric oxide receptor, soluble guanylate cyclase, after formalin injection into the rat hind paw. Neuroscience 112:439-446.

Tao Y-X, Huang Y-Z, Mei L, Johns RA (2000) Expression of PSD-95/SAP90 is critical for NMDA receptor-mediated thermal hyperalgesia in the spinal cord. Neuroscience 98:201-206.

Tejedor FJ, Bokhari A, Rogero O, Gorczyca M, Zhang J, Kim E, Sheng M, Budnik V (1997) Essential role for $d l g$ in synaptic clustering of Shaker K1 channels in vivo. J Neurosci 17:152-159.

Wei F, Wang GD, Kerchner GA, Kim SJ, Xu HM, Chen ZF, Zhuo M (2001) Genetic enhancement of inflammatory pain by forebrain NR2B overexpression. Nat Neurosci 4:164-169.

Yung KK (1998) Localization of glutamate receptors in dorsal horn of rat spinal cord. NeuroReport 9:1639-1644.

Zushida K, Kamei J (2002) Effect of MK-801 on the antinociceptive effect of $\left[\mathrm{D}-\mathrm{Ala}^{2}, \mathrm{~N}-\mathrm{MePhe}^{4}, \mathrm{Gly}^{-\mathrm{ol}^{5}}{ }^{5}\right.$ enkephalin in diabetic mice. Eur J Pharmacol 448:39-44. 